\title{
Towards the Critical Discourse Analysis of Imam Khomeini's Will: Determining Ideological Discourse toward EFL Learning
}

\author{
Bahador Sadeghi (Corresponding Author) \\ English Department, Islamic Azad University, Takestan Branch, Takestan, Iran \\ Mohammad Taghi Hassani \\ Imam Hossein University Tehran \& Islamic Azad University, Takestan Branch, Iran \\ Rasem Ghorbani \\ English Department, Islamic Azad University, Takestan Branch, Takestan, Iran
}

\begin{abstract}
It is an accepted truth that Discourse Analysis is the analysis of language in use. The results of the study showed how discourse analysis can be used in decoding facts and fore- grounded information in Imam Khomeini's will. The discourse description strategy was used to bring out the messages, patterns and themes. This study aims to discuss the realization of Islam and Islamic thought by means of language use in a political discourse that is primarily stranded in Norman Fairclough's tristratal framework in critical discourse analysis. For this, the discursive strategies of the Imam Khomeini the founder of Islamic republic of Iran were examined. In conclusion, the researcher showed that Imam Khomeini's will had a significant inclination toward applying verb tense as a means for ideological act in the text as well as action sentences and passive sentences. Moreover, Imam Khomeini enhanced pluralism against individualism. It seems that the contribution of critical discourse analysis in EFL refers to text appreciation, text critics, as well as enhancement of language competence in political and religious fields.
\end{abstract}

Index Terms-Imam Khomeini's will, discourse strategy, Islamic thought, political discourse, ideological act, EFL learning

\section{INTRODUCTION}

Over the years, several studies have been conducted in the field of discourse analysis with various definitions given to it. Discourse analysis has been applied to the analysis of many literary works by scholars. This investigation is an attempt to take discourse analysis some steps further, using its basic elements such as description to make explicit the implicit aspect of Imam Khomeini's messages. Language plays a critical role in politics for gaining power. It is crucial to decode ideological features typical for Imam Khomeini appeared in his last will. Imam Khomeini's will present policies of the new presupposition of a leader toward Islam and its general significance is enhanced pluralism against individualism. The aim of this paper is to examine the messages, elements and themes of Imam Khomeini's will and its ideological elements. The methods applied in this thesis include the discussion and critical analysis of Imam's will at level of description. The data used in this research are the text in the form of written; the data for analysis are English translation of Imam Khomeini's will by groups of translators. Imam Khomeini's will is one of the most sought books in the world today, Imam Khomeini who has his name as the central subject of discourse for Islamic revolution is possibly the most mentioned name in the universe. However, the interpretation of many of the teachings, messages and events he partook in, are being subjected to diverse meaning explication by several people both in the field of religion and outside religion. A discourse analysis of Imam Khomeini's will attempts to show how elements of discourse analysis can be used in decoding facts and fore grounded information from the will.

Considering the role played by discourse analysis in pedagogical issues, as noted in Wodak (2002) the roots of CDA lies in classical rhetoric, text linguistic, and sociolinguistic, as well as applied linguistic and pragmatics. The notions of ideology, power, hierarchy and gender together with sociological variables were all seen as relevant for an interpretation and explanation of text. The rhetoric, pragmatics and syntax contribute to teaching English. DA's contribution to teaching refers to text analysis and translation studies; that is text analysis and translation studies are production of DA. In the present study researcher analyze the political and divine will of Imam Khomeini to obtain patterns; the analysis that identify which patterns exist in Imam Khomeini's speech. The identification of the patterns contributes to the ESP studies of the studies; for instance, English for peace, English for diplomats, English for preaches.

The present study is an attempt to analyze Imam Khomeini's speech, the speech that is peaceful, penetrate, the speech that have been stated by politicians such as Mahatma Gandhi, Nelson Mandela. It seems that diplomats, preaches and clergymen benefit from the patterns that researcher would obtain in this study. 
The analysis of Imam Khomeini's will was a tool to facilitate understanding the comprehensibility of political texts. In fact comprehensible input improves proficiency level of students in learning. Also the analysis and conclusions from this study can be helpful in reading comprehension of students who are learning English for religious purpose. Not only the patterns and dimensions of Imam Khomeini's will contribute to better understanding of Imam Khomeini's political thought, but also the findings of the study contribute better understanding of reading comprehension of political texts. This article attempted to critically investigate the relationship between language and ideology. Critical Discourse Analysis attempts to reveal hidden meanings, which are ideologically prone in a discourse. This work in other words reflected on insights in Critical Discourse Analysis (CDA) that is uncovering of implicit ideologies in texts. It reveals the underlying ideological prejudices and therefore the exercise of power in texts. (Ebunoluma, 2011) The aim of this thesis is to examine Imam Khomeini's will especially its ideological component using the tools of Critical Discourse Analysis texts.

\section{THEORETICAL UNDERPINNINGS}

\section{Discourse}

Discourse is an extensive term that has various definitions, ranging from linguistics, through sociology, philosophy and other discipline Van Dijk (1988) pointed out that discourse in a wider sense, is a complex unit of language form, meaning and action that might be captured under the notion of communicative events or communicative act. According to Johnston 'discourse means actual instances of communication in the medium of language, while discourses in plural, are conventional ways of talking that create and perpetuate systems of ideology, sets of beliefs about how the world works and what is.

Ruiz Ruiz (2009) based on sociological perspective defined discourse as follow: From a sociological point of view, discourse is defined as any practice by which individuals fill reality with meaning. When defined in these terms, discourse is found in a wide range of forms. Certainly, any social practice from a dance, ritual or a piece of music to a job agreement, myth or cookery custom can be analyzed discursively. Yet the discourse of greatest interest to sociologists is that which takes a verbal form, be it written or spoken. The reason for this special interest in verbal discourse is twofold: a practical one and a theoretical one. In practice, verbal discourse is discourse that can be accessed and examined by the analyst.

Bloor and Bloor (2007) provide six distinctions in definition of discourse:

Discourse- 1 is the highest unit of linguistic description; phonemes, morphemes, words, phrases, clauses, sentences and texts are below; - discourse-2 is a sample of language usage, generally written to be spoken, that is, a speech; discourse- 3 refers to the communication expected in one situation context, alongside one field and register, such as the discourse of law or medicine; - discourse-4 is human interaction through any means, verbal and non-verbal; - discourse5 is spoken interaction only; - discourse-6 stands for the whole communicative event.

Van Dijk (1997) associates discourse with linguistic, cognitive and socio-cultural definitions. He first argues that discourse is described at the syntactic, semantic, stylistic and rhetorical levels. Secondly, he adds that it needs to be understood in terms of the interlocutors" processes of production, reception and understanding. And, thirdly, he points to the social dimension of discourse, which he understands as a sequence of contextualized, controlled and purposeful acts accomplished in society, namely, a form of social action taking place in a context (i.e. physical setting, temporal space plus participants). Since context is mostly cognition, that is, it has to do with our knowledge of social situations and institutions, and of how to use language in them, van Dijk claims that each context controls a specific type of discourse and each discourse depends on a specific type of context.

According to Wodak and Meyer (2001) different definitions of discourse refers to three different trends: The German and Central European tradition, in which the term discourse draws on text linguistics; the Anglo-American tradition, in which discourse refers to written and oral texts; and the Foucauldian tradition, in which discourse is an abstract form of knowledge, understood as cognition and emotions.

According to Widdowson's perspective (2007) texts can be written or spoken, and must be described in linguistic terms and in terms of their intended meaning. Discourse, on the other hand, as text in context, is defined by its effect. In his words, discourse "is the pragmatic process of meaning negotiation", and text, its product. Co-textual relations are concerned with text and contextual relations with discourse; that is, text cohesion depends on discourse coherence.

Based on Fairclough and wodak 1997, cited in Van Dijk ,2000) discourse refers to following senses: Language use in speech and writing, meaning-making in the social process, and a form of social action that is "socially constitutive" and "socially shaped". Fairclough and Wodak add that discourses "are partly realized in ways of using language, but partly in other ways", for example visual semiosis. (p.162) Texts are the only evidence for the existence of discourses, one kind of concrete realization of abstract forms of knowledge; at the same time, they are interactive and influenced by sociolinguistic factors. In the process of constructing themselves in society, individuals internalise discourses that comprise the core of a community of practice, in the sense that such discourses control and organise what can be talked about, how it can be talked about and by whom. Social practices are meaningful and coherent in that they conform to discourse principles. As manifestations of ideologies, discourses form individual and collective consciousness, and consciousness influences people's actions; that is, through the repetition of ideas and statements, discourse solidifies knowledge and reflects shapes and enables social reality. 
According to Andrew Cifford (2009) interpreters in discourse do need to be concerned with lexicon, but it is only apart of their work. Furthermore, interpreters need to be concerned with

From all the above definitions, it is clear that discourse is any writing or spoken speech or text which passes or transmits information from one person to the other. It is symbolic and meaningful, that is it impacts some measures of knowledge and information to the participants taking the context into play.

\section{METHODOLOGY}

\section{Data for study}

The present study is an attempt to analyze Imam Khomeini's Will, under the model of Fairclough in CDA (Fairclough, 1995, 2010). Imam Khomein's will is significant in that his will is one of the most sought books in the world today, Imam Khomeini who has his name as the central subject of discourse for Islamic revolution is possibly the most mentioned name in the universe.

\section{Procedure}

In this study vocabulary, grammar, and ideological features of Imam Khomeini's will critically analyzed according to Fairclough's model. The following elements of Fairclough's framework were considered to function as the criteria for the analysis: description (texture, vocabulary, grammar, syntax, text structure), interpretation (intertextuality, intentionality, speech acts), explanation (relationship between discourse, social and cultural reality). All definitions were briefly presented based on Fairclough's elaboration in theoretical framework section.

The study was a corpus based analysis of Imam Khomeini's will conducted on a descriptive which was carried out on English translation of Imam Khomeini's will. The corpus (Imam Khomeini's will) comprised 10000 words in English which whole text was selected for analysis. The data were gathered by analyzing the vocabulary features, themes, topics and classification of Imam Khomeini’s will.

\section{ANALYSIS}

\section{The analysis of the will at the level of description}

The data of this thesis consist of Imam Khomeini's speech. The reason of choosing this Will refers to application of Imam Khomeini's authorative language in legitimizing government in his leadership in order to establish social and discourse order. The analysis of Imam Khomeini's Will at the level of description we face with the meaningful and exact application of lexicon, usage of pronouns, adverbs and verbs. Proper selection of lexicon in two different ideological positions (Republic VS. Pahlavi), application of pronouns appropriate with discourses and also application of active and passive sentences showed Imam Khomeini's ideological aims in text. Ideological struggles and power relations exercised through lexis and grammatical structure in Imam's will. The CDA research in this thesis was based on analysis of lexical and grammatical structure and their role in the analysis of the will. The researcher attempted to detect the underlying ideological patterns and possible lexical element. The analysis of Imam's wills is important as 1) he was specialist in Islamic pure thought and in the fields of philosophy, Quran and Fig h.2) Imam Khomeini in his will addresses prophets, philosophers, and scientist. He addresses not only Iranian nations but also point out the other nations. 3) Imam's will consist of Islamic beliefs, the position of Thaqalien. That is a valuable source for Islamic nations. the political school thoughts of Imam Khomeini's are :1) integration of religious and politics 2) Firm belief to role of citizens 3) international and global view 4) protection of values and Velayat Faghih 5) Justice.

\section{Values in Imam Khomeini's thought}

A word in the text that ideologically contested is 'Thaqalain'. Thaqalain Hadith is unbroken chain of recorded traditions, dominations a proof positive for all mankind, especially for Muslims in all sects and branches. (Imam Khomeini's will) It appears that this proof is binding on all Muslims who are accountable for it. It is man's guide to moral and material life to the last day. Taghoot and Islam are ideologically different and contested. Taghoot occurs 33 times in the will, whereas Islam is used 60 times. It is clear that Taghoot is represented in a negative way and Islam is demonstrated positively. (Atkins, 2002) Followings are collocations of two contested words.

Taghoot collocation: Bankrupt economy, bribery and dishonesty, followers of Taghoot,

Islamic collocation: Islamic culture, Islamic justice, Islamic economy, Islamic society, Islamic university and school, Islamic unity,

Words with expressive values can be classified in two main ways, those that are positive and associated with Islam and those which are negative and related to Taghooaian and satanic powers. (Atkins, 2002)

Positive connotations: render unity, claim the sanctity, path of god, Divine justice, infallible Imam, blessing of heaven,

Negative connotations: blood thirsty colonialist, exploiting perverts and hypocrites, consumer nations, isolate the clergy, satanic plots , create animosity , criminals of history

\section{Focal lexicon}

Focal lexicon is another aspect of description level in which lexicons play a crucial ideological role. Lexicons carry ideology because they show writers attitude. Following are some focal lexicons. 
invitation to Islam, revival of Islam, identity, the relationship between religious and politics, justice, freedom, independence, conformity to law, unity, culture, democracy, foreign policy, Islamic ummah, divine trust, satanic powers, meek and oppression, sovereignty, exploitation, trumpet, colonialisation, rumor, animosity, Islamize, Sepah and Basij (recruits and volunteer), isolate the clergy, consumer nations,

The analysis shows, the lexicon Islam, Muslim, and Quran have high frequency. The high percentage indicates that Imam Khomeini leaded Iranian nation toward Islam by inspiring Quranic rules, and he gave a new meaning to the life in the framework of Islamic rules.

On the other hand, the high percentage for lexicon, Imam, and religious, sovereignty shows that Imam Khomeini had more inclination toward God's divine and Islamic laws.

Overall, It can be inferred that Imam Khomeini in his will addressed all nations especially Muslims to fight against satanic powers by trusting to Islamic rules to gain their spiritual life needs.

\section{Application of pronouns}

Pronouns are another important factor that constitutes the ideology of writer. Using plural or singular pronouns identify writer's perspective toward collectivism or individualism. Imam Khomeini's will vary from applications of pronouns; but the frequency of plural pronouns is more. The high frequency range of the first person pronouns has several aspect of consideration. Third person plural high frequency usage signal the overcome of collectivism to individualism. Frequency of singular pronouns shows the language intimacy of Imam Khomeini and is a plan to get nearer to reader to events of the will. Imam Khomeini use 'we' because of his position and noble Iranian nation to show his honor to Iranian nation. Therefore Imam Khomeini applied 'we, you, they' in the most sections (B, C, E, G) of the will; he use pronouns 'you', and 'they', mean Iranian nations, and use plural pronouns to signify collectivism to audiences. Following are some examples of pronouns in Imam's will. ( Dorodgarian\&Ghorji, 2012)

The analysis showed that Imam Khomeini use pronoun 'We' as ideological acts. With high percentage of using 'we', it can be claimed the overcoming of collectivism to individualism. Also high frequency of pronoun 'we' in Imam's will shows his position and his honor to Iranian nation.

On the other hand, the normal percentage of for pronoun 'I' shows the intimacy of Imam Khomeini's language and to get reader nearer to events of the will. Also Imam showed his responsibility toward Iranian nation.

\section{Application of verb}

This category involves the application of various tenses. Present and past tenses are used in Imam Khomeini's will to signify his attempt in modernizing the past events and making events believable. Integration of present and past shows the integration of symbolic history with social events of present time. (Ghorji\&Ghasemzadeh, 2011)

The analysis showed the cases of present and past tense as an ideological act. As it is shown, there are $30 \%$ case of present verbs, while the Will by having $21 \%$ past tense, shows less ideological act.

The percentage of $30 \%$ for present tense indicates that Imam Khomeini attempt to modernize the past events. Also he conveys certainty.

With $21 \%$ of using past tense, it can be claimed that Imam Khomeini made events more believable, integration of present and past tense, with percentage of $10 \%$ shows the integration of symbolic history with social events of present time.

\section{Application of active and passive sentences (passivisation)}

The passive voice is often used to portray the agents of an action as unknown, obvious, or unimportant. The passive can also be used to hide an agent who is known, or down play the fact that an agent was involved. The choice between passive and active voice is one of a set of choices which speakers inevitably make in representing actions and events having to do with how semantic roles are mapped onto grammatical structure. (Jonstone, 2000)

Imam Khomeini wanted to convey the messages lies in the hearts of the events through the use of active verbs. Known subjects increase the decision making power of audiences in concluding provide a basic understanding of the text. In different sections of the Will nearly all the sentences are active, that is, actions and subjects are clear. The sentences are active because Imam Khomeini describes the role of each and there is no need to hide different factors in getting results. (Ghorji\&Ghasemzadeh, 2011).

The analysis showed the case of passivisation as an ideological act in Imam Khomeini's will. There are three cases of active sentences, with frequency of 160 in entire text, and four examples of passive verbs with frequency of 40in entire text.

Having percentage of $80 \%$ for active verbs, it is claimed that Imam Khomeini stressed on known subjects which they increase decision making power of readers. With20\% of using passive verbs it can be inferred that Imam Khomeini focused on the importance of object in social and political application and abolishment of subject.

\section{Grammatical aspect (imperatives, affirmatives, question forms)}

In section $\mathrm{D}$, and L, Imam used question form to attract audiences and show the dominance of his discourse. Therefore, most of the sentences in different sections have statement(affirmative) aspects that present Imams claim as universally and in convertibly true(Johnstone,2000) ,but Imam Khomeini imperatively advised all institutes to fulfill their responsibility, also in section $\mathrm{L}$ he advised to officials especially foreign policy to use divine laws to control society. In other sections Imam demanded nations and government to obey divine rules and their leaders 
The analysis cleared that affirmatives can be considered as significant and common strategy for ideological acts to present Imam Khomeini's claims as universally and convertibly true. The analysis showed, there were the lower instances of question form and imperatives. With the low percentage for question form and imperatives, it can be concluded that Imam applied these strategies to show his power in guiding Iranian and attract readers.

\section{Application of action sentences:}

Extensive use of action verbs in Imam's speech is thoughtful. Action sentences are agreement, disagreement, pleasant, and unpleasant sentences (Yarmohamadi, 2004, p.33). the verbs such as 'promise', 'state', 'say', 'honor ', 'proud', 'recommend', are action verbs. Action sentences are reasonable points of Imam's will, because by application of action verb Imam attend readers toward the text and events of the text.

The high percentage of action verbs, they can be considered as important and more common strategies of writer for ideological act. The ideological act that action verbs carry referred to attract readers toward the text and events of the text.

The analysis showed that among action verbs 'proud, and advice with normal percentage have significant inclination toward applying as a means of ideological acts. Generally action verbs with high percentage considered as a more significant strategy in description level.

\section{Synonyms, antonyms, semantic inclusion:}

Over wording refers to the use of many different synonyms or near synonyms. The use of many words for something suggests its ideological significance.

Imam Khomeini in his will in introduction section use God's divine trust synonymous with leader of Islamic sovereignty. In the all sections of the will Taqoot is synonymous with illegitimate and anti-Islamic sovereignty. He also used slinking (Satan) synonym with enemies of religion and truth. The application of the institutions has semantic inclusion that consists of all institutions and organs that exist in Islamic republic of Iran. Imam Khomeini in different sections of the will used Taqootian synonymous with Satan also in introduction Malk synonym with the world of nature, Malakoot-e-Aala synonym with the world of divinity, Thqle-Akbar synonym with holly Quran, Theqle-Kabir synonym with infallible imams. he also used the lexicon Taqootian antonyms with lexicon such as illegitimacy, divine legitimacy, and law sovereignty.

\section{Synonyms, antonyms, semantic inclusion}

Over wording refers to the use of many different synonyms or near synonyms. The use of many words for something suggests its ideological significance (Fairclough, 1993, p.193).

Imam Khomeini in his will in introduction section use God's divine trust synonymous with leader of Islamic sovereignty. In the all sections of the will Taqoot is synonymous with illegitimate and anti-Islamic sovereignty. He also used slinking (Satan) synonym with enemies of religion and truth. The application of the institutions has semantic inclusion that consists of all institutions and organs that exist in Islamic republic of Iran. Imam Khomeini in different sections of the will used Taqootian synonymous with Satan also in introduction Malk synonym with the world of nature, Malakoot-e-Aala synonym with the world of divinity, Thqle-Akbar synonym with holly Quran, Theqle-Kabir synonym with infallible imams. he also used the lexicon Taqootian antonyms with lexicon such as illegitimacy, divine legitimacy, and law sovereignty.

\section{Nominalization:}

Nominalization is another way in which the representation of events, actions, and actors, can be manipulated. Nominalization means using as nouns words that can also be used as verbs, adjectives, or adverbs, either with or without the addition of noun makers like the English -tion. (Johnstone, 2000)

In Imam Khomeini's will the nominalization have not highly formed because he intended to unite audience with his thoughts, divine legitimacy, and acceptable Islamic republic sovereignty through description, interpretation and explanation. Following are some examples of nominalization in Imam Khomeini’s will.

\section{DisCUSSIONS AND CONCLUSIONS}

To reach to a general conclusion for the ideological act of strategies in description level, the researcher found it necessary to analyze and calculate all the obtained data .According to analysis, Imam Khomeini's will had a significant inclination toward applying verb tense as a means for ideological act in the text. Then action sentences with a major distance are the second most frequent strategy of description level. Passivization is the third strategy which carries ideological acts. Moreover, other strategies with minor distances to each other have equivalent role in constructing ideological acts of Imam's will. The high percentage of verb tense, it can be inferred that Imam Khomeini attempt to modernize the past events with using present tense and also conveys certainty of his speech. Using past tense, it can be claimed that Imam Khomeini made events more believable, integration of present and past tense, shows the integration of symbolic history with social events of present time. The rather low percentage of passivization revealed that the will have inclination to use passive sentences to show the importance role of objects in the social and political application and abolishment of subject. Imam Khomeini used passive verbs to despise the opposition and show more power. On the other hand, high percentage of active sentences showed that the messages lie in the hearts of the events through the use of active verbs. Known subjects increase the decision making power of audiences in concluding and provide a basic understanding of the text. The sentences are active because Imam Khomeini describes the role of each and there is no 
need to hide different factors in getting results. The essential ideological elements of Imam Khomeini's will can be summarized in the following concepts:

Integration of religious and politics, Firm belief to role of citizens, Protection of values and Velayat Faghih, Justice, Unity and divine motivation Commitment to Islam and country. The most prominent words utilized by Imam Khomeini are: Taqoot, Anti-Qurann, Muslim, Divine trust, The book of the God (Quran), Islam. Dominance of the personal pronoun "we", shows Imam Khomeini's honor to Iranian nation. Imam Khomeini's choice of lexicalization strengthen the notion of unity and brotherly among the members of Iranian society. The theme of the speech is the need to be performed and extended Islamic roles which should be used as divine trust to rebuild the Iranian nation in the time of crisis. That the discursive event shaped the text - Imam Khomeini cleared out the obsoleteness of Quran and Thqalain in pahlavi's regime, and pointed out oppressions that these two have received and guided nations towards Islam as ideal religion. The will is designed for Muslim and non Muslim nations.

\section{REFERENCES}

[1] Abrahimian, E. (2003). Essays on the Islamic Republic, university of California press Berkeley Los angeles· oxford.

[2] Atkins, A. (2002). Critical Discourse Analysis: A letter to expatriates from the Rt. Hon. Sir Norman Fowler MP, working paper, university of Birmingham.

[3] Clifford, A. (2001). Discourse Theory and Performance-Based Assessment: Two Tools for Professional Interpreting. Translators' Journal, 46, 365-378.

[4] Ebunoluwa, F. M. (2011). Critical discourse analysis of president barak obama. University of Ilorin, Ilorin, Kwara State Nigeria.published thesis.

[5] Fairclough, N. (2010). Critical discourse analysis: The critical study of language. Harlow, England: Longman.

[6] Fairclough, N. (2010). Critical discourse analysis: The critical study of language. Harlow, England: Longman.

[7] Gee, J. P. (1999). An introduction to discourse analysis: Theory and method. Retrieved at June 10 ${ }^{\text {th }}$, 2013, from http://books.google.com.

[8] Ghasemzade, S. A., \& Ghorji, M. (1390). critical discourse analysis of Dr. Non LOve LIs wife more than MOsadegh. Adab pajoheshi, 17, 33-63.

[9] Ghorji, M., \& Dorodgarian, F. (1391). critical discourse anlysis of Koli beside fire. Bahare adab, 1(15).

[10] Khomeini, R. (2007). Imam Khomeini's last will and testament,. Embassy of the Democratic and Popular Republic of Algeria, Interests Section of the Islamic Republic of Iran, 1989).

[11] Johnstone, B. (2000). Discourse analysis. Malden, MA: Blackwell Pub.

[12] Ruiz, J. R. (2009). Sociological Discourse Analysis: Methods and Logic. Forum Qualitative Social Reaserch, 10(2), Art.26page (1-30).

[13] VanDijk, T. A. (1985). Structures of Discourse and Structures of Power,. Communication Yearbook, 12, 18-59.

[14] VanDijk, T. A. (1997). Discourse as structure and process. London, available in: www.hum.uva.nl.

[15] Van Dijk, T. 1997. 'Critical Discourse Analysis' [Online], http://www.hum.uva.nl//teun/cda.htm (accessed 20th feburary2012).

[16] VanDijk, T. A. (2000). Ideology and discourse, a multidisciplinary introduction. Pompeu Fabra University, Barcelona.

[17] VanDijk, T. A. (1988). critical discourse anlysis. In Schiffrin,d.\& Tannen,D.the handbook of critical discourse analysis. blackwell.

[18] Widdowson, H. G. (2007). discourse analysis. oxford univercity press. Oxford Introduction to Language Study ELT. ISBN 9780194389211.

[19] Wodak, R., \& Meyer, M. (2001). Methods of critical discourse analysis. Retrieved at March $14^{\text {th }}, 2013$, from http://www.scribd.com.

[20] Woodak, R. (2002). Aspects of critical discourse. ZfAL, 36, 5-31.

[21] Wodak, R. (2007). Language and ideology, language in ideology. Language and politics, John benjmin publications, 6(1).

[22] Ziae, M. S., Nargesian, A., \& Kiamonfared, M. (2009). the analysis between authorative language with legitimation. modiriat dolati, 3(1), 85-104.

[23] Yarmohammadi, M. L. (2004). In mainsream and critical discourse anlysis. tehran: Hirmis.

Bahador Sadeghi, an assistant professor of Applied Linguistics holds a doctorate degree in TEFL from the University of Isfahan, Iran. He also holds three MAs in TEFL, English Translation and International Relations from Tehran Islamic Azad University, Isfahan University and Allameh Tabatabai University respectively. He has been lecturing different subjects in TEFL, Translation studies, General English and ESP at several universities in Iran for the last twenty years. He has both published and presented a number of articles in some international journals and conferences. He has translated twenty books from English to Persian. He is also a certified translator to the judiciary power in Iran and he has been, as a simultaneous interpreter, actively involved in many national and international seminars, sport events and tourism projects.

Mohammad Taghi Hassani, assistant professor in TEFL at Imam Hossein University, Tehran and Islamic Azad University, Takestan Branch, Iran. His research interests are EFL writing, psycholinguistics, phonetics, contrastive analysis, English for Specific Purposes, and language teaching methodology.

Rasem Ghorbani received his BA in 2000 and MA in 2013 in TEFL from the Department of English Language at Islamic Azad University of Takestan. He is currently teaching English at private schools and high schools in Shahre Qods, Tehran. 